\title{
How Organization Models Impact the Governing of Industrial Symbiosis in Public Wastewater Management. An Explorative Study in Sweden
}

\author{
Karolina Södergren * and Jenny Palm (D)
}

check for

updates

Citation: Södergren, K.; Palm, J. How Organization Models Impact the Governing of Industrial Symbiosis in Public Wastewater Management. An Explorative Study in Sweden. Water 2021, 13, 824. https://doi.org/ $10.3390 /$ w13060824

Academic Editors: Didier Orange, Magali Gerino, Jérôme Harmand, Marjorie Le Bars, Nguyen Thai Huyen and Pascal Breil

Received: 26 January 2021

Accepted: 15 March 2021

Published: 17 March 2021

Publisher's Note: MDPI stays neutral with regard to jurisdictional claims in published maps and institutional affiliations.

Copyright: (c) 2021 by the authors. Licensee MDPI, Basel, Switzerland. This article is an open access article distributed under the terms and conditions of the Creative Commons Attribution (CC BY) license (https:/ / creativecommons.org/licenses/by/ $4.0 /)$.
International Institute for Industrial Environmental Economics, Lund University, P.O. Box 196, SE-221 00 Lund, Sweden; jenny.palm@iiiee.lu.se

* Correspondence: karolina.sodergren@iiiee.lu.se

\begin{abstract}
The industrial symbiosis (IS) landscape is evolving rapidly. While previous studies have argued for the importance of municipalities participating in the governing of IS, research on the implications of different forms of municipal organization is still lacking. This paper aims to investigate how municipal administration and municipally-owned corporations, as two forms of organization, impact the governing of IS in the water and sewage sector. This is explored in relation to the Swedish municipality Simrishamn, which recently underwent changes in the form of organization. Results show that municipal administration contributes to a more inclusive process where many actors can influence and bring ideas and perspectives on how to develop an IS. The risk, however, is that other issues within the municipality are seen as more pressing and, therefore, get prioritized before IS. In corporate form, the development of IS becomes more business-like as the focus is kept on core business. Technology development is strengthened as skills and competencies are promoted through the expertise of the employees. Drawbacks include processes becoming less transparent and political goals, such as citizen welfare not receiving the same level of priority as within municipal administration. There is also a risk that fewer perspectives are included in the process of developing IS, which may inhibit innovation, even if the results also indicate that an increased business focus of the corporate form strengthens the innovation capacity.
\end{abstract}

Keywords: industrial symbiosis; urban water management; wastewater reuse; municipal administration; municipally-owned corporation; municipal corporation

\section{Introduction}

In a world with growing pressures on local and global resources, water remains the essence of life as we know it [1]. Over the past century, however, global water use has intensified by a factor of six [2]. It now continues to grow with ever-increasing populations, economic development, consumption patterns, and resource extraction [2]. Adding to a more unreliable water supply, climate change will exacerbate the situation in all regions, whether already or not yet water-stressed [3]. Indeed, experts have warned of an upsurge in the frequency of extreme weather conditions such as heatwaves, droughts, rainfalls, thunderstorms, and flooding. Problems with leaching, high pathogenic contamination, and pollutant concentration will follow and hence-troubles with decreased water quality and availability [2].

Even in Sweden, a country historically rich in water resources, the effects of climate change are starting to take a toll [4-6]. Consequently, it is becoming "increasingly necessary to consider 'unconventional' water resources in future planning" [2,7]. Wastewater is one example gaining traction across the globe as a way to ensure a more flexible water supply [8-11]. For such wastewater practices to be implemented, however, technologies and policies alone are not enough. Appropriate governance, organization, and business models are required, rooted in the local conditions of the wastewater plants themselves [12,13]. 
Industrial symbiosis (IS) has been defined as a type of business model adept for circular practices, such as the recycling of water, wastewater, energy, materials, etc. [14,15]. In practice, IS is presented as a tangible solution that enables financial and resource efficiency within and across value chains $[16,17]$. It is traditionally set up in a way that one actor's outputs become another actor's inputs, thus allowing for recirculation of resources [18]. As part of the circular economy debate, the EU refers to IS both in the New Circular Economy Action Plan [19] and in the Industry Vision for 2030 [20].

Across the globe, governments are implementing IS as part of their efforts to "circulate" economies and industries [21]. It is also common that state agencies and city governments are the ones driving the IS development. The United States, China, Australia, and Japan are good examples [22-24]. In Sweden, too, municipalities have paved the way for IS. In recent years, there has been a particular upsurge within the public water and sewage sector [25]. Several municipalities are now looking into IS as a means for enabling circular water management in their local constituencies.

There is increasing recognition that innovation is needed to overcome challenges in the water sector, but still, innovative circular solutions are under-researched in the water sector [26]. IS in the water and sewage sector can maximize the efficient use of resources and generate less waste [27]. In the wastewater sector, one symbiosis solution could be to create a collaboration where one actor (company/organization) using virgin water agrees to swap this and use wastewater generated from another actor instead.

Despite the promises inherent to IS, the potential for uptake of new local synergies is limited by both technical and non-technical barriers [28]. Barriers to IS identified in earlier research include, e.g., different investment cycles of organizations [29] as well as not knowing how to divide incomes and costs between organizations [30]. When it comes to wastewater, a barrier can also be that it increases the operational costs for the industries involved connected to new treatment procedures [29,31]. Moreover, companies often work in silos without contact with each other [28,32]. This can be linked to a lack of willingness to collaborate [33] or lack of trust between organizations [34-36]. The lack of a cooperative mechanism for making organizations collaborate with each other also makes this the ultimate enabler [28].

Municipalities can be an important player in overcoming barriers and especially when it comes to barriers related to collaboration and networking [28]. Lenhart et al. [37], for example, studied how the municipal administration supported IS in Rotterdam in the Netherlands. Van Berkel et al. [35,38] analyzed the symbiotic relationships between industries and municipalities in an eco-town program in Japan. A common role for municipal administrations has been to create meeting arenas and contribute to communication and information sharing between actors [29,39,40]. Lenhart et al. [37] concluded that municipal administrations were active in the design of IS projects but not in the implementation phase.

These earlier studies were used as a point of departure for this paper, which aims to expand previous research on IS and look deeper into the role of municipalities and their internal organization of the water and sewage sector. Recognizing that little attention has been given to questions regarding the public organization and governing [41], the article seeks to explore how public organization models matter for governing IS in the water and sewage sector. Specifically, it investigates how municipal administration and municipally-owned corporations, as two common forms of organizations, may bring different implications for IS implementation.

The article is structured in the following manner. In Section 2, conceptual underpinnings of IS are presented, as well as the organizational foundations of Swedish water and sewage management. Section 3 outlines the materials and methods applied to this paper. Section 4 provides the results and analysis of how public organization models matter for governing IS in the water and sewage sector. The paper concludes with Section 5, which discusses the key takeaways and potential future developments of this research field. 


\section{Theory}

\subsection{Industrial Symbiosis-Organization and Governing}

In earlier research, the dynamics and evolution of different IS networks have been studied (e.g., [27,28,42-46]). Although some IS literature traditionally centered on industries, attention has since diverted towards other types of actor roles as well [47]. Mortensen \& Kørnøv [48] argue that public actors have proven particularly important for the initial IS emergence. This includes national, regional, and local entities such as governmental agencies, public agencies, and municipalities [49-54]. According to Mortensen and Kørnøv [48], public actors can "seed the innovation process into a local context". This by, e.g., providing support and access to specialized knowledge. Patricio et al. [55] also emphasize the role of municipal administration in grounding IS to a local context, while Lombardi \& Laybourn [56] and Abreu \& Ceglia [57] emphasize municipal administration in relation to the convening power and clarification of policy and regulation. Abreu \& Ceglia [57] also pointed to the importance of municipalities having diverse resources come together and creating adequate support through policies, legislation, economic and market instruments.

In some studies, public organizations have been identified as anchor tenants [58-61], especially so in an institutional context [24]. Martin and Eklund [62] explain that: "Anchor tenants do not have to be physical anchor tenants [...]. They may also take the form of institutional anchor tenants which aim to provide systems with information, social and economic infrastructure, decision-making forums, and institutional and political support." Public actors, such as municipalities, can thus promote IS to find synergies between actors to further economic welfare and an environmental image for the community as well as for the actors involved.

Municipalities have also been emphasized within urban industrial symbioses [38,63-65]. Building on the attributes of IS, urban industrial symbiosis focuses specifically on urban sub-systems as important parts of an IS [37]. Investigating Japan's government-led ecotown program, van Berkel et al. [38] suggest that IS arises from the synergistic opportunities evolving from the geographic proximity of industrial and domestic urban waste sources and their potential industrial users. Lenhart et al. [37] later studied IS in Rotterdam. Focusing on the public sector particularly, they discussed new and critical roles for municipalities in supporting symbiotic resource exchanges.

While the role of municipalities in IS thus covers quite some depth, little research has explored the type of governing best suited for such collaborative systems. Walls and Paquin [47] briefly approach the topic in their article on organization perspectives in IS, suggesting that network or participatory forms of governance may be effective. Velenturf [66] also introduce the topic in her study of the governance system in the Humber region, UK. Focusing on the implementation of resource efficiency policy and regulation, she divides potential governmental activities into strategic or operational categories.

Still lacking from the debate are discussions on how different ways of publicly organizing a sector may impact the governing of IS. The way municipal services are organized, decide what regulations are applicable (e.g., a corporation must adhere to ordinary legislation governing private limited companies), how services are subject to guidelines and regulations were drawn up by municipal decision-making bodies, such as the municipal council and municipal boards, and the extent to which the municipality as an owner can control the services [67]. Public organization forms can thus be assumed to impact how IS is governed and developed. To address this gap, this paper analyzes how municipal administration and municipal corporations, as different organization models, influence symbiosis in the water and sewage sector.

\subsection{Municipal Organization of the Water and Sewage Sector}

Water is an important public good, and water services are usually regulated both at national and supranational levels. At an EU level, the water framework directive (WFD) and the "water industry" directives (e.g., the drinking water directive (DWD), the urban wastew- 
ater treatment directive (UWWTD), and the bathing water directive (BWD)) govern the environmental and health standards and are implemented in national legislation [68]. How to organize water services is a decision made by the member states of the EU. According to EurEau [68], there are four main models:

- Direct public management, where the public entity is entirely in charge of service provision and their management;

- Delegated public management, where a management entity is appointed by the responsible public entity to execute the management tasks. Usually, this management entity is owned by the public sector;

- Delegated private management, where the responsible public entity appoints a private company to manage tasks based on a time-bound contract in the form of a lease or concession contract. The ownership of the infrastructure remains in the hands of the public, but the duties are subcontracted to a private company;

- Direct private management, where all management tasks, responsibilities, and ownership of water utilities are placed in the hands of private operators. The role of the public is to control and regulate. Within Europe, this system is only in place in England, Wales, and the Czech Republic.

In our analysis, we focus on the first two points—direct and delegated public management, which relate to municipal administration and municipal corporation (see Table 1).

In Sweden, the Public Water Services Act (SFS 2006:412) regulates that municipalities are responsible actors for providing accurate water and sewage supply, based on sound financial management in the short- and long-term [69]. Public water services are funded through fees according to the self-cost principle. Different governing and organization models exist for managing water and sewage in municipalities, where the basic organizing principles are to put it in the administration or to place it into a municipal corporation that is either owned by one or several municipalities. Table 1 summarizes the key characterizations of the different organization models.

Table 1. Different forms of municipal organization of water and sewage. Based on [70-72].

\begin{tabular}{|c|c|c|c|}
\hline & Municipal Administration & Municipal Corporation & Multi-Municipal Corporation \\
\hline Definition & $\begin{array}{l}\text { Administrative departments of the } \\
\text { Municipality entrusted by the city } \\
\text { manager to assist with the } \\
\text { overseeing, implementation, and } \\
\text { compliance with, e.g., water supply }\end{array}$ & $\begin{array}{l}\text { A corporation owned by one } \\
\text { municipality }\end{array}$ & $\begin{array}{l}\text { A corporation jointly owned by } \\
\text { two or more municipalities }\end{array}$ \\
\hline Control & Political control & $\begin{array}{l}\text { The municipal owns the } \\
\text { corporation and elects a } \\
\text { corporation board }\end{array}$ & $\begin{array}{l}\text { Joint ownership by multiple } \\
\text { municipalities } \\
\text { Jointly elect a corporation board }\end{array}$ \\
\hline Goals of organization & $\begin{array}{l}\text { Political control and civic value; } \\
\text { Serve inhabitants }\end{array}$ & $\begin{array}{l}\text { Multiple and often conflicting } \\
\text { goals. Typically, the logic of } \\
\text { political control and civic } \\
\text { value is mixed with the logic } \\
\text { of profit-making }\end{array}$ & $\begin{array}{l}\text { Multiple and often conflicting } \\
\text { goals. Typically, the logic of } \\
\text { political control and civic value } \\
\text { is mixed with the logic of } \\
\text { profit-making } \\
\text { Characterized by agreements } \\
\text { and negotiations between } \\
\text { municipalities }\end{array}$ \\
\hline $\begin{array}{l}\text { Mechanisms of } \\
\text { operation }\end{array}$ & $\begin{array}{c}\text { Hierarchically organized/ } \\
\text { bureaucratic administration/ } \\
\text { monitoring, scrutiny, interventions }\end{array}$ & $\begin{array}{l}\text { Bureaucratic and price } \\
\text { mechanisms }\end{array}$ & $\begin{array}{l}\text { Bureaucratic and price } \\
\text { mechanisms }\end{array}$ \\
\hline Resources & $\begin{array}{c}\text { Defined by the municipal border, all } \\
\text { municipal sectors, and resources } \\
\text { Resource charges based on taxation } \\
\text { and fees }\end{array}$ & $\begin{array}{l}\text { Driven by financial returns, } \\
\text { customers, and business case } \\
\text { Inhabitants are typically } \\
\text { charged for resources at a } \\
\text { self-cost price }\end{array}$ & $\begin{array}{l}\text { Driven by financial returns, } \\
\text { customers, and business case } \\
\text { Inhabitants are typically } \\
\text { charged for resources at a } \\
\text { self-cost price }\end{array}$ \\
\hline
\end{tabular}


The most frequent form of organization in the water and sewage sector is direct public management through municipal administration (61\%). This means that a municipality has organized both strategic planning and the operation of water and sewage services within the framework of municipal administration $[73,74]$. The operational responsibility is often delegated to a municipal department, such as the department for technology or the department for civil, environmental and natural resources. Water and sewage management, therefore, rarely stands alone but remains included as part of additional departmental duties [75].

Previous studies have shown many benefits with keeping water and sewage in the municipal administration, including increased transparency and control [76]. While the municipality may lose influence if activities are no longer kept under its premises, keeping a full overview of the water and sewage operations allows for a more holistic understanding of when and what decisions need to be made [75]. Municipal administration also allows for proximity between different municipal functions, a factor that facilitates collaboration and community building [75]. The sense of community, in turn, gives rise to a culture characterized by loyalty and support. Moreover, when different departments and functions act as one unity, citizens and other stakeholders experience a stronger sense of accountability [77].

For smaller and medium-sized municipalities, however, a challenge with municipal administration regards the difficulty in recruiting and keeping good personnel, as well as in finding the right competencies for performing specialized tasks [75]. Moreover, staff working in small municipalities tend to have limited time and space for handling new demands and future planning. Commonly, the focus remains on managing day-to-day operations, and everything else becomes down prioritized or performed by externally hired consultants. Governing in the form of independent municipal administration, therefore, carries a risk of vulnerability since the municipality may not be able to keep up with developments in the longer term [77]. This is also why a common solution is to govern water and sewage management through a municipal corporation that is either owned by one or several municipalities [75]. Here, the corporation becomes the head principal and also the owner of the water and sewage plant(s) in question.

Organizing public services into corporate form has a long tradition in Sweden; however, it received an additional boost in the mid-1980s with the influence of new public management [78]. Since then, this model has become increasingly popular, and $39 \%$ of the organizations in the water and sewage sector are municipal corporations owned by one or more municipalities. In this type of delegated public management, the municipal council acts as the owner, but all tasks, responsibilities, and ownership of water utilities are placed in the municipal corporation. The municipal council elects the municipal company's board, and the appointment process is entirely political [79]. In addition to the municipal council, the municipal executive board monitors company performance and ensures that it in line with the owner's directives and the purpose of the company [80].

In joint corporations, a similar process takes place, although the numerous participating municipalities must agree together with other shareholders in a shareholder agreement on how the ownership is to be exercised [81]. Joint owned corporation facilitates intermunicipal cooperation.

Municipally-owned corporations are valued for enabling shorter decision-making processes, a clearer responsibility of the profits, larger financial freedom of action, and, therefore, enhanced efficiency $[67,78]$. The shorter decision-making process is linked particularly to the fact that less political control brings effectiveness to managing the dayto-day operations. Another attribute is linked to the municipal corporation operating as an independent legal entity. As finances, income, and balance sheets are separate from the local government's; the financial management is said to become more straightforward in a public corporation [78]. It also has proved beneficial to municipal corporations in that they do not get pulled into negative priorities and cutbacks that may occur within the municipal 
administration. In some ways, this independence also means the corporations can embody a more distinct identity towards their external environment [82].

The fundamental difference between conducting public services in administrative and corporate forms lies in the separation of ownership and control brought by this latter. Since the owner (the municipal council and politicians) hands over the control to the company's management (the board and CEO), a separation occurs between these functions [78,80]. As part of trying to reduce this gap, it is common that the municipal council proposes politicians to become involved in the board [82].

Researchers argue that the transparency of the company gets limited as the distance between the company and external stakeholders increases. For citizens, this becomes problematic for determining who is ultimately responsible for the outcomes of the public corporation. Impaired transparency is thus said to reduce the democratic influence over public activities [83]. Although democratic transparency is supposed to be applied to municipal corporations in the same way as for the municipality as a whole, citizens cannot appeal against operational decisions [81]. The main opportunity for citizens to influence the design of municipal activities (such as corporations) is during local political elections.

Up for debate is also the combination of public and corporate values and goals found in municipal corporations [84,85]. According to Pahl-Wostl [86], this is by no means straightforward. Rather, it is considered to bring ambiguity, ineffectiveness, and a conflict of interest both within the organization and between the organization and its stakeholders [79]. It is also not rare that one set of values and goals take the lead over the other in the day-today operations, leading to mission drift and loss of legitimacy [79]. According to Alexius and Furusten [87], organizational hybridity, such as in the case of municipal corporations, is, therefore, "a double-edged sword for management and governance because, in essence, managing complexity is a challenge, and stepping out of the norm always invites questions and often also confusion".

As described above, there are some important factors needed for IS to emerge and develop, including relevant governing actors, goals and ambitions, policies, and resources $[17,49,88]$. These are the factors that will be specifically focused on in our analysis and discussed in relation to different organization forms. Figure 1 showcases these factors, as well as what aspects are discussed for each of them. Other factors could be envisaged as well; however, these were brought to the forefront in our empirical data collection. The analytical framework below thus emerged from an abductive process, where both theory and empirical data influenced the final design.

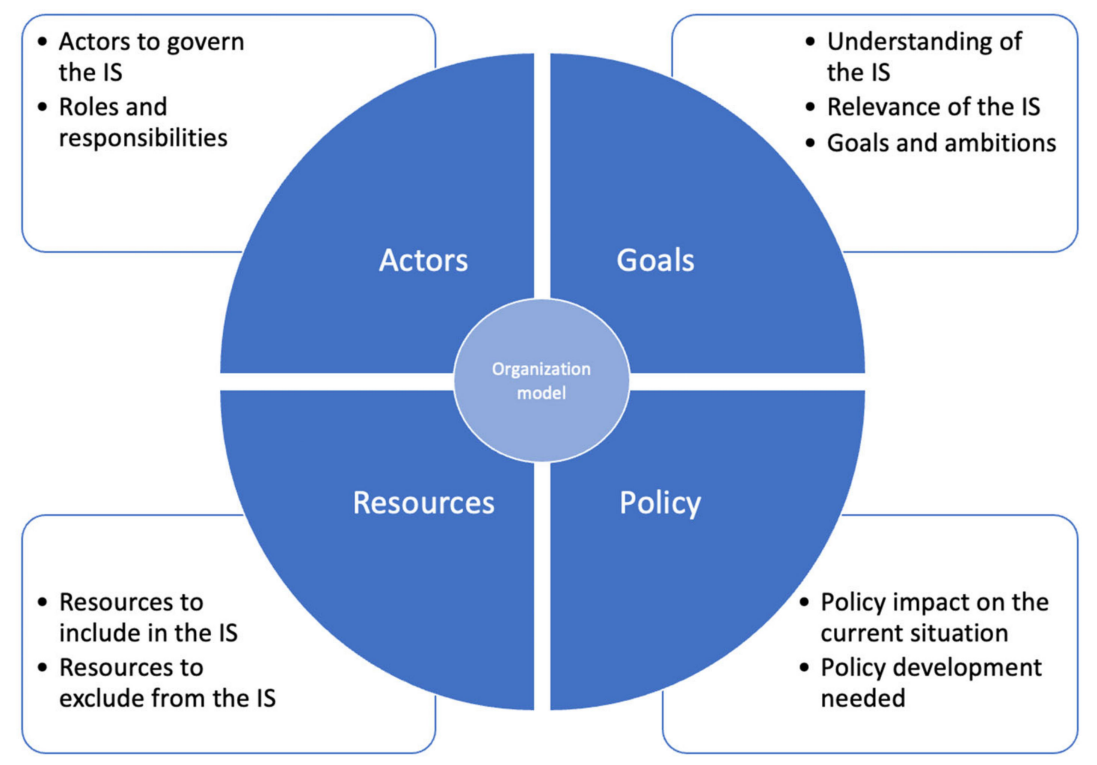

Figure 1. Framework for analyzing the impact of organization forms on actors, goals, resources, and policy in industrial symbiosis. 


\section{Materials and Methods}

This paper represents an explorative study of how organization models may impact the governing of IS in public wastewater management. Explorative studies open up for creative approaches that can contribute to raising new questions or reaching new insights about a phenomenon [89]. The empirical material comes from Simrishamn, which presents a topical case for illustrating since the municipality recently has changed the organizational form of the water and waste service.

Simrishamn is a municipality situated along the Baltic Sea in the southeast of Sweden. Simrishamn has approximately 19,500 inhabitants, of which 6000 live in the urban area of Simrishamn. Approximately half of the municipality's area consists of cultivated arable land, while the rest consists of forest and meadowland as well as residential areas.

The municipality has around 3000 registered companies, mostly small- and mediumsized companies. About 600 are active in agriculture and fruit farming [90]. Although modest in size with a total surface of $393 \mathrm{~km}^{2}$, the municipality of Simrishamn innovates and develops new technological solutions for local wastewater management. Simrishamn is currently upgrading three wastewater plants (Stengården, Kivik, and St Olof) with top modern filtering and monitoring technologies. At the backdrop lies an ambition to reach more sustainable and efficient wastewater practices because of problems with low groundwater reserves on the municipal grounds [91]. IS seen as a part of this solution, and the municipality is, therefore, exploring potential strategies for connecting resource and material flows going forward. During the period of data collection, Simrishamn underwent a restructuring of its water and sewage organization model, which was previously organized in the municipal administration. In November 2019, the municipal council of Simrishamn decided to establish a water and sewage corporation together with the neighboring municipality Tomelilla. The analysis in this article focuses on the arguments behind this change in organizational form in Simrishamn.

Data collection took place between September 2019 and January 2021 through the use of multiple methods. Participatory observations were conducted on five different occasions as part of the data collection process. These observations consisted of the first author following different officials in the municipality (both in the administration and in the corporation) and observed their everyday work, e.g., participating in meetings or following the activities people were engaged in. These observations are mainly used as background information in this article and not analyzed per se. It was during the observations that the change in organization form was identified as a topic of interest, and it was decided to change the focus of the research project to also include this process. Due to this unplanned change in focus, the other municipality, Tomelilla, has not been researched, and this article, therefore, only focuses on the process in Simrishamn.

Throughout the research, documents were gathered from websites, newspapers, and the Water and Sewage Department archives to track relevant political and organizational decision-making processes linked to the strategic development of the water and sewage sector in Simrishamn. Books, articles, and reports were also consulted to examine the evolution of IS in the wastewater sector in Sweden over time.

Semistructured interviews were conducted between September 2019 and December 2019 (see Table 2 below). Interviewees were identified through a stakeholder mapping exercise conducted with the municipality. They were selected based on working with developing — or having an interest in exploring-IS around wastewater. More than twenty interviews were conducted, but in this paper, only the interviews relevant for the change in organization form are analyzed. Table 2 (see below) summarizes the interviewees that were relevant to this paper. 
Table 2. Interviews conducted relevant for the change in organization form in the municipality.

\begin{tabular}{ccc}
\hline$\#$ & Interviewees & Organization \\
\hline 1 & Director & Water and sewage dep./corp \\
2 & Project manager & Water and sewage dep./corp \\
3 & Site manager & Water and sewage dep./corp \\
4 & Senior manager & Simrishamn municipality \\
5 & R\&D manager & Simrishamn municipality \\
6 & Project manager & Simrishamn municipality \\
7 & Project manager & Simrishamn municipality \\
8 & Director & Simrishamn municipality \\
9 & Business developer & Simrishamn municipality \\
10 & Procurement manager & Simrishamn municipality \\
\hline
\end{tabular}

In terms of questions, they were asked about their academic and professional background, current role, and expertise. They were also asked to reflect upon key characteristics of the municipality as well as the level and quality of collaboration as it currently stands between different actors (public, private, NGOs). From here, they were asked to elaborate on the concepts of circular economy and IS, describe their understanding of them, as well as their views on how applicable they are for the municipality and region at large. They were asked to consider how a circular economy and IS could be set up on the local grounds, what would be critical resources to include, how to organize it, and whom to be responsible for the organization. They were specifically asked about the role of the municipality as a public organization, its strengths and weaknesses concerning IS. They were also given the time and space to reflect upon any questions related to those outlined above, typically in line with their respective field of work. Interviews were conducted in Swedish, face-to-face and took between one to two hours. They were recorded and transcribed into text files.

\section{Results}

Below we discuss how the meaning and relevance of actors, goals, resources, and policy changes depending on whether the water and sewage system is organized within public administration or in a corporate form.

\subsection{Actors and Organizations}

As mentioned above, Simrishamn has gone from organizing water and sewage within the municipal administration to a joint corporation with another municipality [92]. An advantage of having it in the administration was, according to the interviewees, that the connection to other departments and activities within the municipality was clear, and it contributed to a holistic understanding of what activities the municipality engaged in. It also enabled better collaboration, which is an essential aspect in a small municipality.

It's easier for an organization that belongs to the municipal administration to do this type of work. (Interviewee 1)

Collaboration in a small municipality like Simrishamn ends up on a personal level. It really depends on what people there are. Sometimes it works, sometimes it doesn't work at all. But in a small municipality, everything ought to be collaborative. (Interviewee 6)

Others meant that the development of IS around water and sewage was a task for the municipal government, which was a reason to keep it under direct control, i.e., organize it within the administration:

The municipality should be the one holding the hands of companies. (Interviewee 2)

Rural development often becomes a regional responsibility, and regions put work where the money is. Responsibility should lie with the municipalities instead. They can operate as a collaborative platform for development. They can take more of a developmental role, not just a basic role that costs money. (Interviewee 3) 
When organizing water and sewage in a corporation, the municipality remained an owner and, therefore, had an important role to play [93]. It did, however, change how the everyday activities were run. According to some, this meant that water and sewage services could be run in a more business-like manner:

The key is to look at it as a business opportunity. Not to make money but to lower the costs. (Interviewee 4)

A public corporation allows for reaching a critical mass so that you can have a form of economies of scale for the work that is there. [...] That way, you can use resources in a completely different way. (Interviewee 4)

It appears that the advantage of having water and sewage in a municipal corporation is that it can be more efficient. When organized in corporate form, other and fewer actors became involved in the day-to-day activities and in deciding on, e.g., technological development. It was, therefore, easier to drive the development of services in a corporation. According to some of the interviewees, the increased business focus of the corporate form strengthened the innovation capacity. Interviewees also suggested a market-driven organization with clearer separation between the owner and the everyday governing of the system benefitted a more cost-efficient functioning of the system. Moreover, it helped safeguard interests related to water service vis-à-vis other organizations and activities in situations of conflict [92].

\subsection{Goals and Ambitions}

Organization models also influenced what goals and ambitions were put forward for the IS. The interviewees agreed that a municipal administration had other goals to fulfill than a municipal corporation [93]. The administration must consider citizen welfare and make sure to have a fair service provision for all.

The role of the municipality, which should not be forgotten, is to safeguard the most basic fundaments, such as school, healthcare, etc. (Interviewee 3)

When organizing the same activities in a corporation, the goals changed. As mentioned above, the organization became more business-like [93]. The development of a business model, therefore, became more in focus than it did in the municipal administration.

About symbiosis, we need to find business models that work for understanding when resources are used and how (Interviewee 4 )

When setting up the water and sewage system within the municipal administration, the political responsibilities were considered as better clarified compared to in the municipally-owned corporation. Basic democratic principles, such as transparency and public participation, were also easier to achieve in the administration [93].

As regards the role of the municipality, all decisions should always benefit the largest possible number of inhabitants. (Interviewee 6)

Another advantage within the municipal administration was that it was easier to anchor decisions and make them a political priority. In a corporation, the activities boiled down to responsibilities over balance sheets and financial status. Other issues of importance for a municipal government tended to receive less prioritization. Indeed, provided services were related to what has been contracted in the corporation, instead of a more general responsibility based on political accountability [83].

The local government has a responsibility in driving societal development. As in the case of environmental problems, the public sector often must impel solutions until they are economically viable for businesses to pursue. (Interviewee 1)

\subsection{Resources for Industrial Symbiosis}

One advantage mentioned for municipal administration regards it is easier to consider multiple and different resources of use and value for the municipality. The municipal 
government works with many sectors, such as water, sludge, energy, fishery, harbor development, and public transport. The municipal administration was in a natural way part of the discussions on how to develop the municipality in a way that benefits all these areas. When in corporate form, the municipality gathered competencies and resources specific to water and sewage in one place with clearer responsibility boundaries [92]. This can be seen as benefitting the development of expert knowledge in one specific area. However, it might be at the expense of a broader, general understanding of what is going on in the whole municipality.

Municipalities can be precursors and open for the circular economy and industrial symbiosis by investigating different types of flows on the local grounds. (Interviewee 1)

Yes, I believe symbiosis belongs here. There are already a few examples of where this is happening in the area. The thinking is there, with resources at different ends that you can bring together (Interviewee 2)

In a corporate form, resources were also more clearly linked to what type of input data were available and what kinds of customers would be willing to engage in the symbiosis.

We need in-data. To identify future partners, understand future touchpoints. To know if there are buyers for future products. (Interviewee 4)

One informant emphasized that it would be of utmost importance to clarify the business case of the resources envisioned for the IS (water, in the case of the corporation) to attract customers.

We need to develop a business case for water. For farmers, this could be better yield, better revenue, better economy - plus better environment. If we are to reach a circular system, there have to be gains for everybody. The values need to be understood and clarified, for the consumer and producer. (Interviewee 9)

The employees in the municipal corporation were, however, aware of the company being municipally owned, with a broader responsibility than privately owned ones [94].

No other than the municipality can drive the development because water and sewage lie under it [belongs to it according to the law]. (Interviewee 5)

The municipality is a platform, to work and live in. For citizens and work opportunities. It's like the spider in the net. (Interviewee 7)

Moreover, a system perspective seemed to have been kept in the municipal corporation, as the employees took a broader view of water and sewage services and how these are situated in context.

You can have a symbiosis in many different ways with many different products. It's geographically bounded. It boils down to an energy question-it has to be balanced and off-set against each other. (Interviewee 4)

If you look at water and sewage, the treatment plant is an important piece of the puzzle for an environmentally friendly symbiosis. (Interviewee 7)

A benefit of having the system in an administration is that it can rely on resources from the municipality. Swedish municipalities have far-reaching autonomy and raise their own taxes. When organizing water and sewage in corporate form, the company has its budget based on customer fees. This gives the corporation freedom to make independent decisions, free from political consideration, and only consider what is best from, for example, a business perspective [93]. However, it can also be a disadvantage, for example, in times of high-risk investment, when it can be useful to have a municipal budget to rely on. 


\subsection{Policy Issues and Developments}

When the municipal council is responsible for establishing and maintaining water and sewage services, the development of municipal policy, integration of different interests, resources and stakeholders become important parts.

Despite this fact, the Community Planning Committee of Simrishamn municipality discussed difficulties in keeping "deep knowledge" of water and sewage issues when having an administrative setup. The reason being the competition with other areas of the administration, such as health and education, which often ended up being prioritized [92].

One person commented that when organizing water and sewage in municipal administration, the municipal council takes the liberty to experiment and develop new ideas.

The driving force lies in doing something that nobody else has done. Develop and improve (Interviewee 5)

When water and sewage are in corporate form, the action space of the municipal council and the municipal board becomes restricted and municipal policymaking is not applicable in the same way [93]. Instead, owner directives, national (and international) regulations become guiding principles. Being under the direct control of the municipal council and the municipal board could indicate that there is a possibility to directly influence national legislation through the municipal politicians. This view was, however, not represented under the interviews. Rather it seemed like the actors saw a possibility to change policies and legislation by setting an example and show alternative solutions. The interviewees working in the water and sewage corporation described ideas they had discussed to challenge the legislation:

We want to see what happens if you test legislation and policy differently. The legislation is based on the end destination of the water. But what happens if you change this? Maybe the legislation is completely wrong? Did they build the water and sewage system wrongly? (Interviewee 4)

There should be legislation for doing it [circulating water resources]. We need more, and maybe more than legislation. (Interviewee 5)

Development of IS as such was also seen as a way to go around the legislation that sometimes worked as a barrier for further development.

It i's problematic to judge each organization number for itself, but if two companies join together in a symbiosis - in a new business idea with a clear business plan where waste never becomes waste - then you will avoid the complicated waste legislation [that applies in some instances]. I would really like to see this happen. (Interviewee 8)

There were, however, different views on whether IS is best developed through practical collaborative projects or through developing clear circular policies. If there was a clear circular policy in place, it would benefit the mapping of potential symbiosis solutions.

\subsection{Summary of the Benefits and Strengths}

Table 3 summarizes the benefits and weaknesses discussed in the documents and by the interviewees in relation to the two different organization forms. 
Table 3. Summary of benefits and weaknesses with different organization forms identified in Simrishamn.

\begin{tabular}{|c|c|c|}
\hline & Benefits & Weaknesses \\
\hline Municipal administration & $\begin{array}{c}\text { Holistic municipal perspective, easy to find } \\
\text { cross-sectoral benefits and solutions } \\
\text { Political control and clear political responsibilities } \\
\text { Citizen welfare and fair service } \\
\text { provisionTransparency and accountability } \\
\text { Municipal circular economy and IS } \\
\text { Having the municipal budget as back-up } \\
\text { Integration of municipal policy } \\
\text { Experimentation }\end{array}$ & $\begin{array}{l}\text { Other prioritizations than water and sewage } \\
\text { System boundaries are identical with the } \\
\text { municipal geographical borders } \\
\text { Less competitive on a market } \\
\text { Hard to attract experts }\end{array}$ \\
\hline Municipal corporation & $\begin{array}{c}\text { Business in focus } \\
\text { Budget independent of municipal politics } \\
\text { Customer focus } \\
\text { Cost-efficiency } \\
\text { Innovation } \\
\text { Focus on core activity (water and sewage) } \\
\text { Expert knowledge } \\
\text { New business models }\end{array}$ & $\begin{array}{c}\text { The municipality act as an owner, indirect } \\
\text { political control } \\
\text { Municipal policy less influential } \\
\text { Municipal prioritizations harder to } \\
\text { implement } \\
\text { Lack of general understanding of the } \\
\text { municipality and a broader perspective } \\
\text { Customer rather than citizen focus }\end{array}$ \\
\hline
\end{tabular}

\section{Conclusions}

The above analysis explores how IS in the water and sewage sector is influenced by forms of organization. Earlier studies have discussed the importance of organization for control and management of a sector $[67,75]$. Our study supports this, showing that the choice of the organization will have implications for the development of IS in the water and sewage sector-at least when it comes to the actor, goal, policy, and resource-related factors that were studied herein. The choice of organization impacts, who is invited, which interest becomes represented, and what issues are included in the process to develop an IS.

When the system is kept within the municipal administration, it benefits a holistic municipal perspective, implying that it would be easier to find cross-sectoral benefits and solutions when all parts are kept within a municipality [22,25]. The analysis also supports the idea that issues such as transparency and accountability are more important when services are kept within the municipal administration. Additionally, users will be seen in the light of citizenship rather than as customers, which has been discussed by, e.g., Mattisson and Thomasson [77].

In a corporate form, the development of the IS is more business-like and values, such as cost-efficiency and innovation, prevail $[67,78]$. When organizing water and sewage services in a corporation, it becomes a separate municipal entity that can be decided on independently, although it relies on collected fees. The separation between the municipal government and the water and sewage system will thus be clearer-something that can potentially contribute to making decisions more in line with factual issues at hand. However, it also changes the governing political principle of the system, as the municipal government will govern the company through owner directives and by deciding on members of the board.

If many different resources are to be part of the IS, it appears more effective to keep water and sewage services within the municipal administration due to this form benefitting an all-inclusive view on both sectors and actors. A limitation with municipal administration, however, regards the principal focus of what happens inside of municipal geographical borders [81]. Especially for small-sized municipalities, this may bring a risk of missing out on what lies beyond [75]. A corporation does not see municipal borders in the same way, and therefore, may find it easier to discover regional and national collaborations [75]. In the case of Simrishamn, the corporation ended up as jointly owned by two municipalities, which blurs the municipal boundaries even further. 
These features are highlighted under Resources in Figure 2 below, which provides a summary of how municipal administration and corporation differently impact actor, goal, resource, and policy-related issues in IS for the water and sewage sector.

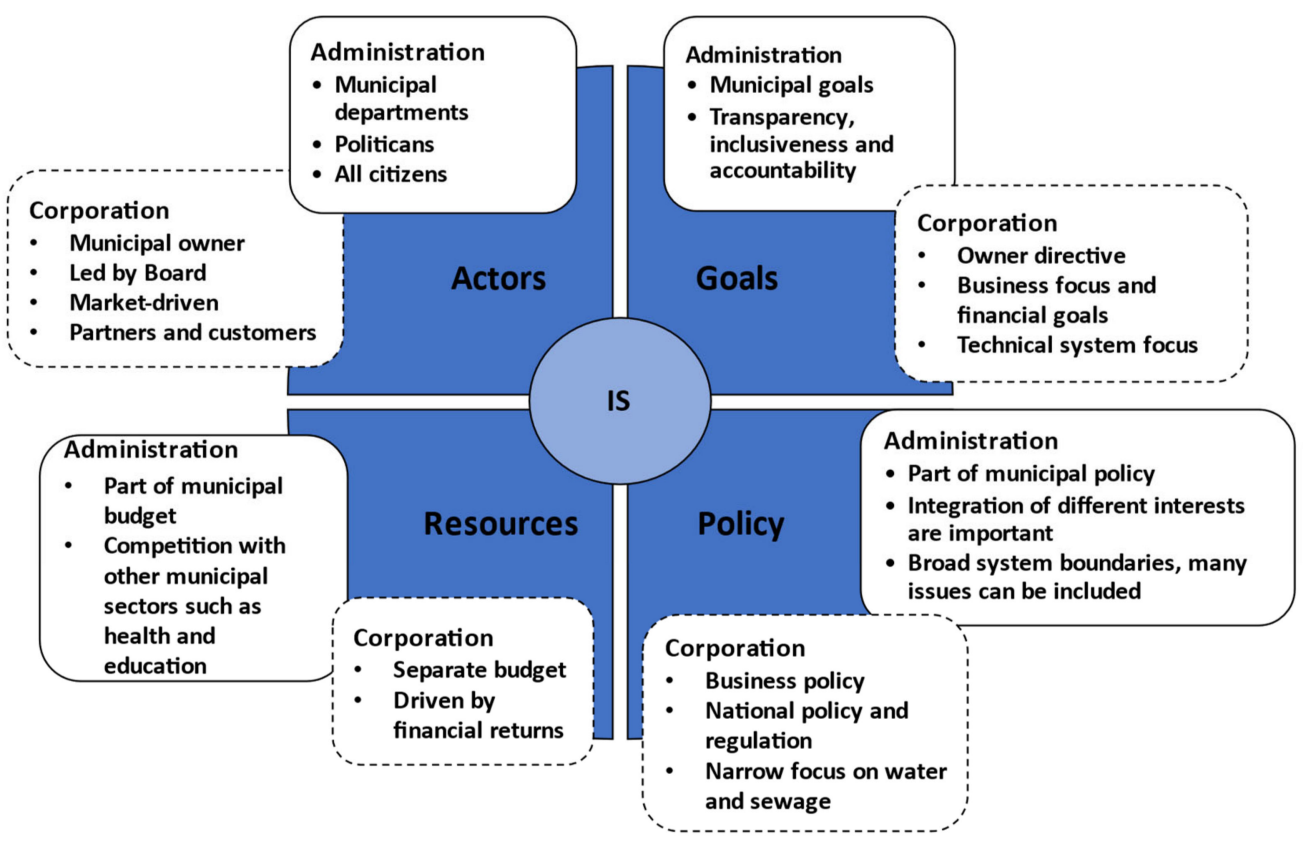

Figure 2. Analytical framework showcasing the impact of public organization forms on actors, goals, resources, and policy in industrial symbiosis.

There were mixed opinions on whether the administrative or corporate form benefitted innovation most (compare, e.g., [48,79]). It seemed, however, like the employees in the water and sewage corporation in Simrishamn felt more freedom to think beyond existing regulations and come up with new ideas on how to pass or change rules. The municipal administration, on the other hand, works closer to the municipal council and municipal board and could influence national and international levels of policymaking through direct contact with politicians [75]. This was, however, not discussed among our informants.

Departing from a topical case of a Swedish municipality, this paper zoomed in on the water and sewage sector. In conclusion, this paper investigated how different models of public organization impact governing of IS in a small city of Sweden. In sum, we found that in municipal administration, more diversity of both actors and issues are included, which opens up for the possibilities to bring in different ideas and perspectives on how to develop IS in the municipality. At the same time, the administration is under the direct control of the municipal council and its budget, meaning that other issues than water and sewage may be seen as more pressing and thus become prioritized when the budget is allocated. In a corporate form, the development of the IS becomes more business-like, where values and resources are focused on cost-efficiency. The municipal corporation has control over its own budget and, by that, its prioritizations. With this, however, processes become less transparent for both politicians and citizens, and political goals and citizen welfare are no longer in focus the same way as within an administration. There is a risk that fewer perspectives are included in the process of developing IS, which can restrict innovation. On the other hand, a corporation can keep the focus on its core business, attract staff with core competence in the area, and prioritize technology development. Taken together, this implies that the choice of organization form has implications for what kind of issues and actors are involved when municipal IS emerge.

Simrishamn investigated the pros and cons of creating a municipal corporation, and this was discussed on several occasions in the municipal council and the municipal board. The reasons why they chose to create a corporation, in the end, were that they wanted the 
service to be run more like a business, they wanted to be able to maintain a focus on the core area of operation (e.g., water and sewage), and they thought it would contribute to attracting more competent personnel.

The paper is based on a single case study, where only the key persons in Simrishamn municipality involved in the process of establishing a jointly owned water and sewage corporation were interviewed. This represents a starting point for further research expanding the discussions on how governing and organization forms matter for IS. For future research, it would be interesting to also interview, e.g., private industrial companies and citizens in Simrishamn, to have their view on IS and organizational form. Additional case studies could be conducted for comparative reasons, as well as to focus on other factors that may impact IS development. One such factor is how joint ownership influences municipal processes in the establishment of an IS. Future case studies could be used to expand the analytical framework presented herein, as well as to try it out in different sectors and industries.

Author Contributions: Conceptualization, K.S. and J.P.; methodology, K.S. and J.P.; validation, K.S. and J.P.; formal analysis, K.S. and J.P.; data curation, K.S.; writing-original draft preparation, K.S. and J.P.; writing—review and editing, K.S. and J.P.; visualization, K.S. and J.P.; supervision, J.P.; project administration, K.S. and J.P.; funding acquisition, J.P. All authors have read and agreed to the published version of the manuscript.

Funding: This research was funded by the Swedish Energy Agency, grant number 46,016-1.

Institutional Review Board Statement: Ethical review and approval were not waived for this study. According to the Swedish Ethical Review Act (2003:460) ethical review is not required for this research, due to that this research does not processing of special categories of personal data according to the General Data Protection Regulation (EU 2016/679); does not processing of personal data regarding violations of law that include crimes, judgments in criminal cases, penal law sanctions, or administrative deprivation of liberty; does not include physical interventions on research subjects or deceased persons; does not include methods with the purpose of affecting a research person physically or mentally, or which includes an apparent risk of injuring the research subject either physically or mentally; does not studies of biological material that has been taken from a living or deceased person, and can be traced to that person.

Informed Consent Statement: Informed consent was obtained from all subjects involved in the study.

Data Availability Statement: The data presented in this study are available on request from the corresponding author. The data are not publicly available due to that it could compromise participant anonymity.

Acknowledgments: We want to thank the editor and reviewers for valuable comments, which helped us to not only clarify but also develop the analysis in this paper.

Conflicts of Interest: The authors declare no conflict of interest. The funders had no role in the design of the study, in the collection, analyses, or interpretation of data, in the writing of the manuscript, or in the decision to publish the results.

\section{References}

1. Gawlik, B.M.; Easton, P.; Koop, S.; Van Leeuwen, K.; Elelman, R. Urban Water Atlas for Europe; Publications Office of the European Union Luxembourg: Luxembourg, 2017.

2. UNESCO, U.-W. United Nations World Water Development Report 2020:Water and Climate Change; UNESCO: Paris, France, 2020.

3. Bisselink, B.; Bernhard, J.; Gelati, E.; Adamovic, M.; Guenther, S.; Mentaschi, L.; De Roo, A. Impact of a changing climate, land use, and water usage on Europe's water resources. In EUR 29130 EN; Publications Office of the European Union Luxembourg: Luxembourg, 2018.

4. Stensen, K.; Krunegård, A.; Rasmusson, K.; Matti, B.; Hjerdt, N. Sveriges Vattentillgång Utifrån Perspektivet Vattenbrist och Torka:Delrapport 1 i Regeringsuppdrag om Åtgärder för att Motverka Vattenbrist $i$ Ytvattentäkter; Swedish Meteorological and Hydrological Institute (SMHI): Norrköping, Sweden, 2019.

5. Hogdin, S.; Gustafsson, H.; Liveland, R.; Sorby, L. Fördelning av Vatten i Torkans spår: Redovisning av Regeringsuppdrag Gällande Möjligheter att Använda Föreskrifter för att Motverka Allvarlig Vattenbrist; Havs-och vattenmyndigheten: Göteborg, Sweden, 2018. 
6. Sjöstrand, K.; Lindhe, A.; Söderqvist, T.; Rosén, L. Water supply delivery failures-A scenario-based approach to assess economic losses and risk reduction options. Water 2020, 12, 1746. [CrossRef]

7. Alcalde-Sanz, L.; Gawlik, B. Minimum Quality Requirements for Water Reuse in Agricultural Irrigation and Aquifer Recharge. Towards A Legal Instrument on Water Reuse at EU Level, EUR 28962 EN; Publications Office of the European Union: Luxembourg, 2017.

8. European Commission. Closing the Loop-An EU Action Plan for the Circular Economy, COM (2015) 614 Final; European Commission: Brussels, Belgium, 2015.

9. IEA. Water-Energy Nexus; IEA: Paris, France, 2017.

10. UNESCO World Water Assessment Programme. The United Nations World Water Development Report, 2017: Wastewater: The Untapped Resource; UNESCO: Paris, France, 2017.

11. Leal Filho, W. Climate Change and the Sustainable Use of Water Resources [Elektronisk Resurs]; Springer: Berlin, Germany, 2012.

12. Carvalho, L.; Mackay, E.B.; Cardoso, A.C.; Baattrup-Pedersen, A.; Birk, S.; Blackstock, K.L.; Borics, G.; Borja, A.; Feld, C.K.; Ferreira, M.T. Protecting and restoring Europe's waters: An analysis of the future development needs of the Water Framework Directive. Sci. Total Environ. 2019, 658, 1228-1238. [CrossRef]

13. SOU 2019:66. En Utvecklad Vattenförvaltning; Norstedts juridik: Stockholm, Sweden, 2019.

14. Bocken, N.M.; De Pauw, I.; Bakker, C.; Van Der Grinten, B. Product design and business model strategies for a circular economy. J. Ind. Prod. Eng. 2016, 33, 308-320. [CrossRef]

15. Bocken, N.M.; Short, S.W.; Rana, P.; Evans, S. A literature and practice review to develop sustainable business model archetypes. J. Clean. Prod. 2014, 65, 42-56. [CrossRef]

16. Tumilar, A.S.; Milani, D.; Cohn, Z.; Florin, N.; Abbas, A. A Modelling Framework for the Conceptual Design of Low-Emission Eco-Industrial Parks in the Circular Economy: A Case for Algae-Centered Business Consortia. Water 2021, 13, 69. [CrossRef]

17. Baldassarre, B.; Schepers, M.; Bocken, N.; Cuppen, E.; Korevaar, G.; Calabretta, G. Industrial Symbiosis: Towards a design process for eco-industrial clusters by integrating Circular Economy and Industrial Ecology perspectives. J. Clean. Prod. 2019, 216, 446-460. [CrossRef]

18. Boons, F.; Spekkink, W.; Isenmann, R.; Baas, L.; Eklund, M.; Brullot, S.; Deutz, P.; Gibbs, D.; Massard, G.; Romero, E.; et al. Comparing industrial symbiosis in Europe: Towards a conceptual framework and research methodology. In International Perspectives on Industrial Ecology; Deutz, P., Lyons, D., Bi, J., Eds.; Edward Elgar Publishing: Cheltenham, UK, 2015 ; pp. 69-88.

19. European Commission. A New Circular Economy Action Plan For a Cleaner and More Competitive Europe; European Commission: Brussels, Belgium, 2020.

20. European Commission. A vision for the European industry until 2030. In Final Report of the Industry 2030 High Level Industrial Roundtable; Publications Office of the European Union: Luxembourg, 2019. [CrossRef]

21. Thieriot, H.; Sawyer, D. Development of Eco-Efficient Industrial Parks in China: A Review; International Institute for Sustainable Development: Winnipeg, MB, Canada, 2015.

22. Huang, B.; Yong, G.; Zhao, J.; Domenech, T.; Liu, Z.; Chiu, S.F.; McDowall, W.; Bleischwitz, R.; Liu, J.; Yao, Y. Review of the development of China's Eco-industrial Park standard system. Resour. Conserv. Recycl. 2019, 140, 137-144. [CrossRef]

23. Geng, Y.; Doberstein, B. Developing the circular economy in China: Challenges and opportunities for achieving'leapfrog development'. Int. J. Sustain. Dev. World Ecol. 2008, 15, 231-239. [CrossRef]

24. Wang, Q.; Deutz, P.; Chen, Y. Building institutional capacity for industrial symbiosis development: A case study of an industrial symbiosis coordination network in China. J. Clean. Prod. 2017, 142, 1571-1582. [CrossRef]

25. Hoyer, K. Återvunnet Avloppsvatten för Industriell Användning och Bevattning; Svenskt Vatten: Bromma, Sweden, 2019.

26. Sousa-Zomer, T.T.; Miguel, P.A.C. Sustainable business models as an innovation strategy in the water sector: An empirical investigation of a sustainable product-service system. J. Clean. Prod. 2018, 171, S119-S129. [CrossRef]

27. Chertow, M.R. Industrial symbiosis: Literature and taxonomy. Annu. Rev. Energy Environ. 2000, 25, 313-337. [CrossRef]

28. Södergren, K.; Palm, J. The role of local governments in overcoming barriers to industrial symbiosis. Clean. Environ. Syst. 2021, 2, 100014. [CrossRef]

29. Madsen, J.K.; Boisen, N.; Nielsen, L.U.; Tackmann, L.H. Industrial Symbiosis Exchanges: Developing a Guideline to Companies. Waste Biomass Valorization 2015, 6, 855-864. [CrossRef]

30. Fichtner, W.; Tietze-Stöckinger, I.; Frank, M.; Rentz, O. Barriers of interorganisational environmental management: Two case studies on industrial symbiosis. Prog. Ind. Ecol. Int. J. 2005, 2, 73-88. [CrossRef]

31. Islam, K.; Rahman, M.; Islam, K. Industrial symbiosis: A review on uncovering approaches, opportunities, barriers and policies. J. Civ. Eng. Environ. Sci. 2016, 2, 011-019. [CrossRef]

32. Golev, A.; Corder, G.D.; Giurco, D.P. Barriers to Industrial Symbiosis: Insights from the Use of a Maturity Grid. J. Ind. Ecol. 2015, 19, 141-153. [CrossRef]

33. Park, H.S.; Rene, E.R.; Choi, S.M.; Chiu, A.S.F. Strategies for sustainable development of industrial park in Ulsan, South KoreaFrom spontaneous evolution to systematic expansion of industrial symbiosis. J. Environ. Manag. 2008, 87, 1-13. [CrossRef] [PubMed]

34. Chertow, M.; Ehrenfeld, J. Organizing Self-Organizing Systems: Toward a Theory of Industrial Symbiosis. J. Ind. Ecol. 2012, 16, 13-27. [CrossRef]

35. Bossilkov, A.; Van Berkel, R.; Corder, G. Regional Synergies for Sustainable Resource Processing: A Status Report; Centre for Sustainable Resource Processing: Perth, WA, Australia, 2005. 
36. Bacudio, L.R.; Benjamin, M.F.D.; Eusebio, R.C.P.; Holaysan, S.A.K.; Promentilla, M.A.B.; Yu, K.D.S.; Aviso, K.B. Analyzing barriers to implementing industrial symbiosis networks using DEMATEL. Sustain. Prod. Consum. 2016, 7, 57-65. [CrossRef]

37. Lenhart, J.; Van Vliet, B.; Mol, A.P.J. New roles for local authorities in a time of climate change: The Rotterdam Energy Approach and Planning as a case of urban symbiosis. J. Clean. Prod. 2015, 107, 593-601. [CrossRef]

38. Van Berkel, R.; Fujita, T.; Hashimoto, S.; Geng, Y. Industrial and urban symbiosis in Japan: Analysis of the Eco-Town program 1997-2006. J. Environ. Manag. 2009, 90, 1544-1556. [CrossRef]

39. Levänen, J.O.; Hukkinen, J.I. A methodology for facilitating the feedback between mental models and institutional change in industrial ecosystem governance: A waste management case-study from northern Finland. Ecol. Econ. 2013, 87, 15-23. [CrossRef]

40. Palm, J.; Smedby, N.; McCormick, K. The role of local governments in governing sustainable consumption and sharing cities. In $A$ Research Agenda for Sustainble Consumption Governance; Mont, O., Ed.; Edward Elgar Publishing: Cheltenham, UK, 2019.

41. Neves, A.; Godina, R.; Azevedo, S.G.; Matias, J.C. A comprehensive review of industrial symbiosis. J. Clean. Prod. 2020, 247, 119113. [CrossRef]

42. Boons, F.; Spekkink, W.; Mouzakitis, Y. The dynamics of industrial symbiosis: A proposal for a conceptual framework based upon a comprehensive literature review. J. Clean. Prod. 2011, 19, 905-911. [CrossRef]

43. Boons, F.; Chertow, M.; Park, J.; Spekkink, W.; Shi, H. Industrial symbiosis dynamics and the problem of equivalence: Proposal for a comparative framework. J. Ind. Ecol. 2017, 21, 938-952. [CrossRef]

44. Doménech, T.; Davies, M. The role of embeddedness in industrial symbiosis networks: Phases in the evolution of industrial symbiosis networks. Bus. Strategy Environ. 2011, 20, 281-296. [CrossRef]

45. Gibbs, D.; Deutz, P. Reflections on implementing industrial ecology through eco-industrial park development. J. Clean. Prod. 2007, 15, 1683-1695. [CrossRef]

46. Paquin, R.L.; Howard-Grenville, J. The evolution of facilitated industrial symbiosis. J. Ind. Ecol. 2012, 16, 83-93. [CrossRef]

47. Walls, J.L.; Paquin, R.L. Organizational Perspectives of Industrial Symbiosis: A Review and Synthesis. Organ. Environ. 2015, 28, 32-53. [CrossRef]

48. Mortensen, L.; Kørnøv, L. Critical factors for industrial symbiosis emergence process. J. Clean. Prod. 2019, 212, 56-69. [CrossRef]

49. Costa, I.; Ferrão, P. A case study of industrial symbiosis development using a middle-out approach. J. Clean. Prod. 2010, 18, 984-992. [CrossRef]

50. Panyathanakun, V.; Tantayanon, S.; Tingsabhat, C.; Charmondusit, K. Development of eco-industrial estates in Thailand: Initiatives in the northern region community-based eco-industrial estate. J. Clean. Prod. 2013, 51, 71-79. [CrossRef]

51. Van Beers, D.; Bossilkov, A.; Lund, C. Development of large scale reuses of inorganic by-products in Australia: The case study of Kwinana, Western Australia. Resour. Conserv. Recycl. 2009, 53, 365-378. [CrossRef]

52. Van Beers, D.; Bossilkov, A.; Corder, G.; Van Berkel, R. Industrial symbiosis in the Australian minerals industry: The cases of Kwinana and Gladstone. J. Ind. Ecol. 2007, 11, 55-72. [CrossRef]

53. Taddeo, R.; Simboli, A.; Morgante, A. Implementing eco-industrial parks in existing clusters. Findings from a historical Italian chemical site. J. Clean. Prod. 2012, 33, 22-29. [CrossRef]

54. Park, J.M.; Park, J.Y.; Park, H.-S. A review of the National Eco-Industrial Park Development Program in Korea: Progress and achievements in the first phase, 2005-2010. J. Clean. Prod. 2016, 114, 33-44. [CrossRef]

55. Patricio, J.; Axelsson, L.; Blomé, S.; Rosado, L. Enabling industrial symbiosis collaborations between SMEs from a regional perspective. J. Clean. Prod. 2018, 202, 1120-1130. [CrossRef]

56. Lombardi, D.R.; Laybourn, P. Redefining industrial symbiosis: Crossing academic_Practitioner boundaries. J. Ind. Ecol. 2012, 16, 28-37. [CrossRef]

57. De Abreu, M.C.S.; Ceglia, D. On the implementation of a circular economy: The role of institutional capacity-building through industrial symbiosis. Resour. Conserv. Recycl. 2018, 138, 99-109. [CrossRef]

58. Korhonen, J. Theory of industrial ecology: The case of the concept of diversity. Prog. Ind. Ecol. Int. J. 2005, 2, 35-72. [CrossRef]

59. Korhonen, J. Some suggestions for regional industrial ecosystems-Extended industrial ecology. Eco-Manag. Audit. J. Corp. Environ. Manag. 2001, 8, 57-69. [CrossRef]

60. Lehtoranta, S.; Nissinen, A.; Mattila, T.; Melanen, M. Industrial symbiosis and the policy instruments of sustainable consumption and production. J. Clean. Prod. 2011, 19, 1865-1875. [CrossRef]

61. Sun, L.; Spekkink, W.; Cuppen, E.; Korevaar, G. Coordination of industrial symbiosis through anchoring. Sustainability 2017, 9, 549. [CrossRef]

62. Martin, M.; Eklund, M. Improving the environmental performance of biofuels with industrial symbiosis. Biomass Bioenergy 2011, 35, 1747-1755. [CrossRef]

63. Simboli, A.; Taddeo, R.; Raggi, A. The multiple dimensions of urban contexts in an industrial ecology perspective: An integrative framework. Int. J. Life Cycle Assess. 2019, 24, 1285-1296. [CrossRef]

64. Ness, D.A.; Xing, K. Toward a Resource-Efficient Built Environment: A Literature Review and Conceptual Model. J. Ind. Ecol. 2017, 21, 572-592. [CrossRef]

65. Kim, H.-W.; Dong, L.; Choi, A.E.S.; Fujii, M.; Fujita, T.; Park, H.-S. Co-benefit potential of industrial and urban symbiosis using waste heat from industrial park in Ulsan, Korea. Resour. Conserv. Recycl. 2018, 135, 225-234. [CrossRef]

66. Velenturf, A.P. Analysing the governance system for the promotion of industrial symbiosis in the Humber region, UK. People Place Policy Online 2016, 10, 146-173. [CrossRef] 
67. Palm, J. Development of sustainable energy systems in Swedish municipalities: A matter of path dependency and power relations. Local Environ. 2006, 11, 445-457. [CrossRef]

68. EurEau. The Governance of Water Services in Europe. Available online: http://www.eureau.org/resources/publications/150report-on-the-governance-of-water-services-in-europe/ file2018 (accessed on 25 February 2021).

69. Najar, N.; Persson, K.M. Strategies, Processes, and Results for the Future Water Supply of the Växjö Municipality: Evaluation of an Evidence-Based Case Study of Long-Term Strategies within the Water and Wastewater Sector in Sweden. Water 2019, 11, 2150. [CrossRef]

70. Svenskt Vatten. Svenska VA-Organisationer. Available online: https://www.svensktvatten.se/va-chefens-verktygslada/vaorganisationen/ (accessed on 25 February 2021).

71. Pahl-Wostl, C. An evolutionary perspective on water governance: From understanding to transformation. Water Resour. Manag. 2017, 31, 2917-2932. [CrossRef]

72. Niehaves, B.; Plattfaut, R.; Sarker, S. Understanding Dynamic IS Capabilities for Effective Process Change: A Theoretical Framework and an Empirical Application. 2011. Available online: http:// citeseerx.ist.psu.edu/viewdoc/download?doi=10.1.1.2 31.4551\&rep=rep1\&type=pdf (accessed on 16 March 2021).

73. Lingsten, A. Kartläggning av Organisationsformer inom VA-Branschen i Sverige; Svenskt Vatten: Stockholm, Sweden, 2010.

74. Thomasson, A. Organisering för Ökad Uthållighet-En Studie av Olika Organisationsformer Inom den Svenska VA-Sektorn; Svenskt Vatten: Stockholm, Sweden, 2013.

75. Thomasson, A. Att Driva VA Fliegen Förvaltning-Den Lilla Kommunens Erfarenheter Och Utmaningar; Svenskt Vatten: Stockolm, Sweden, 2015.

76. Sveriges Kommuner och Landsting (SKL). Offentligt och Privat Driven Verksamhet. Vilka Legala Skillnader Finns? SKL: Stockholm, Sweden, 2011.

77. Mattisson, O.; Thomasson, A. Interkommunal Samverkan-en Kunskapsöversikt. In Underlagsrapport till Kommunutredningen (Fi 2017: 02); Lunds Universite: Lund, Sweden, 2019.

78. Erlingsson, G.Ó.; Fogelgren, M.; Olsson, F.; Thomasson, A.; Öhrvall, R. Hur Styrs och Granskas Kommunala Bolag?: Erfarenheter och Lärdomar från Norrköpings Kommun; Linköping University: Linköping, Sweden, 2014.

79. Thomasson, A. The importance of the owner relationship in shaping hybrid organizations. In Managing Hybrid Organizations; Springer: Cham, Switzerland, 2019; pp. 129-155.

80. Palm, J. Makten över Energin: Policyprocesser i två Kommuner 1977-2001. Ph.D. Thesis, Linköping University, Linköping, Sweden, 2004.

81. Bergman, E. Interkommunal Samverkan-en Nödvändig Lösning på Kommunala Utmaningar? Göterborg Universitet: Göteborg, Sweden, 2013.

82. Sveriges Kommuner och Landsting (SKL). VA i Samverkan. Samverkansformer Inom Vatten-E Avloppsförsörjning; SKL: Stockholm, Sweden, 2005.

83. Wihlborg, E.; Palm, J. Who is governing what? Governing local technical systems-An issue of accountability. Local Gov. Stud. 2008, 34, 349-362. [CrossRef]

84. Battilana, J.; Dorado, S. Building sustainable hybrid organizations: The case of commercial microfinance organizations. Acad. Manag. J. 2010, 53, 1419-1440. [CrossRef]

85. Jay, J. Navigating paradox as a mechanism of change and innovation in hybrid organizations. Acad. Manag. J. 2013, 56, 137-159. [CrossRef]

86. Pahl-Wostl, C. A conceptual framework for analysing adaptive capacity and multi-level learning processes in resource governance regimes. Glob. Environ. Chang. 2009, 19, 354-365. [CrossRef]

87. Alexius, S.; Furusten, S. Managing Hybrid Organizations: Governance, Professionalism and Regulation; Palgrave Macmillan: London, UK, 2019.

88. Domenech, T.; Bleischwitz, R.; Doranova, A.; Panayotopoulos, D.; Roman, L. Mapping Industrial Symbiosis Development in Europe_typologies of networks, characteristics, performance and contribution to the Circular Economy. Resour. Conserv. Recycl. 2019, 141, 76-98. [CrossRef]

89. Stebbins, R.A. Exploratory Research in the Social Sciences; Sage: Thousand Oaks, CA, USA, 2001.

90. Simrishamn Municipality. Available online: www.simrishamn.se (accessed on 21 February 2021).

91. Länsstyrelsen Skåne. Regional Vattenförsörjningsplan för Skåne Län; Länsstyrelsen Skåne: Malmö, Sweden, 2012.

92. Simrishamn Municipality. Simrishamns Kommun. Samhällsbyggnadsnämnden. Sammanträdesprotokoll 2019-09-26; Simrishamn Kommun: Simrishamn, Sweden, 2019.

93. Brink, H. Simrishamns Kommun och Tomelilla Kommun. VA-Samverkan. Uppdragsnummer 13005096. VA-System Syd.; Sweco: Stockholm, Sweden, 2019.

94. Simrishamn Municipality. Simrishamns Kommun. Förslag Ägardirektiv. 19-10-31; Simrishamn Municipality: Simrishamn, Sweden, 2019. 